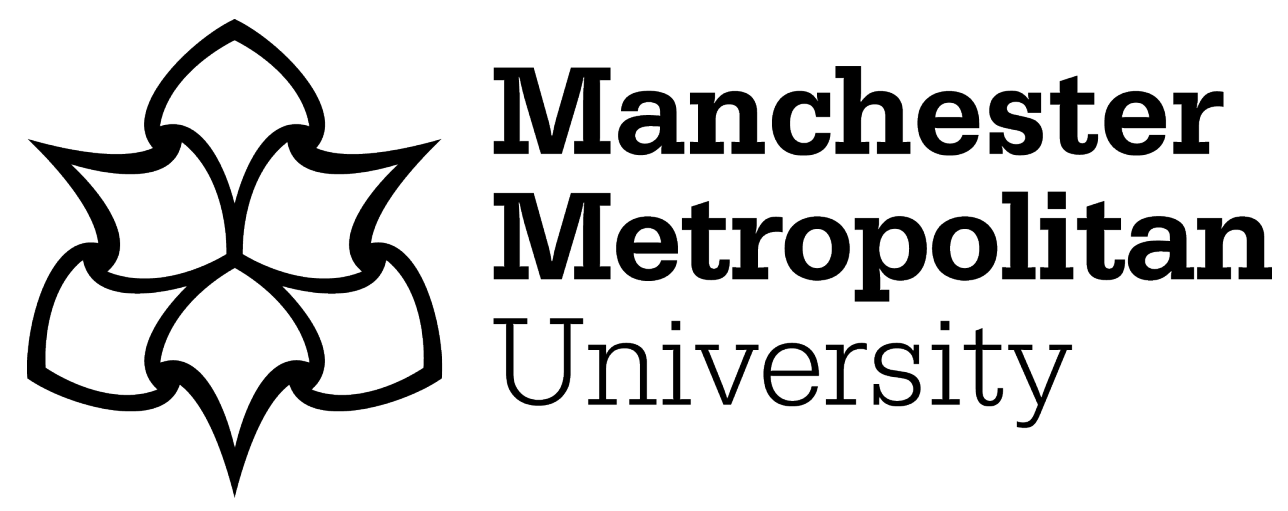

Leguina, A, Widdop, P ORCID logoORCID: https://orcid.org/0000-00030334-7053 and Tampubolon, $G$ (2016) The global omnivore: Identifying musical taste groups in Austria, England, Israel and Serbia. Sociological Research Online, 21 (3).

Downloaded from: https://e-space.mmu.ac.uk/624975/

Version: Accepted Version

Publisher: Sage

DOI: https://doi.org/10.5153/sro.4020

Please cite the published version 


\title{
The Global Omnivore: Identifying Musical Taste Groups in Austria, England, Israel and Serbia
}

\author{
by Adrian Leguina, Paul Widdop and Gindo Tampubolon \\ Research Associate; Research Fellow; Senior Research Fellow
}

Sociological Research Online, 21 (3), 15

$<$ http://www.socresonline.org.uk/21/3/15.html>

DOI: $10.5153 /$ sro.4020

Received: 10 Dec 2015 | Accepted: 18 Aug 2016 I Published: 31 Aug 2016

\begin{abstract}
This research offers a unique opportunity to revisit the omnivore hypothesis under a unified method of cross-national analysis. To accomplish this, we interpret omnivourism as a special case of cultural eclecticism (Ollivier, 2008; Ollivier, Gauthier and Truong, 2009). Our methodological approach incorporates the simultaneous analysis of locally produced and globally known musical genres. Its objective is to verify whether cultural omnivourism is a widespread phenomenon, and to determine to what extent any conclusions can be generalised across countries with different social structures and different levels of cultural openness. To truly understand the scope of the omnivourism hypothesis, we argue that it is essential to perform a cross-national comparison to test the hypothesis within a range of social, political and cultural contexts, and a reflection of different historical and cultural repertoires (Lamont, 1992).
\end{abstract}

Keywords: Cultural Omnivore, Cultural Capital, Consumption, Bourdieu

Introduction

In the early 1990s, American sociologist Richard Peterson and his collaborators produced a stream of work that initiated a change of paradigm regarding American musical taste and how it acts as a status marker on several stratification axes (Peterson 2005). Over the last two decades, the omnivore/univore hypothesis has influenced a body of research that uses cultural terms to explain the symbolic stratification of contemporary societies. However, only a limited amount make comparisons between countries (Katz-Gerro 2002; Lizardo and Skiles 2009; Chan 2010; Birkelund and Lemel 2013).

This research offers a unique opportunity to revisit the omnivore hypothesis under a unified method of cross-national analysis. To accomplish this, we interpret omnivourism as a special case of cultural eclecticism (Ollivier 2008; Ollivier, Gauthier and Truong 2009). Our methodological approach incorporates the simultaneous analysis of locally produced and globally known musical genres. Its objective is to verify whether cultural omnivourism is a widespread phenomenon, and to determine to what extent any conclusions can be generalised across countries with different social structures. To truly understand the scope of the omnivourism hypothesis, we argue that it is essential to perform a cross-national comparison to test the hypothesis within a range of social, political and cultural contexts, and a reflection of different historical and cultural repertoires (Lamont 1992).

\section{Distinction and omnivores}

Explanations regarding the existence of several homogeneous patterns of cultural engagement have been intensely developed and have emerged from different traditions, arguing a clear association between lifestyles and economic and social characteristics (Daloz 2010). These theoretical frameworks differ mainly in their explanations of the mechanisms that shape the relationship between culture and social stratification. Through what was an innovative theoretical and empirical approach for his time, Pierre Bourdieu's homology thesis makes possible an understanding of how 1960s' French social classes can be hierarchically distinguished in terms of their cultural consumption. Put simply[1], homology hypothesis extracted from Bourdieu's seminal work La Distinction (Bourdieu 1984) has frequently being stated as: Social stratification axes are (highly) correlated with lifestyles and more specifically, higher (lower) social positions tend to prefer (reject) what are traditionally accepted as highbrow musical genres, while lower (higher) social positions prefer (reject) lowbrow (Leguina 2015). 
lowbrow cultural activities (univores) (Peterson and Simkus 1992; Peterson 2005). Not exempt from criticism, the work of Peterson and his colleagues nevertheless encountered a generally positive reception, and during the past twenty years several refinements to the taste omnivourism theory have been made.

From several national contexts, the variety of evidence questions cultural omnivourism as an explanation of contemporary cultural engagement. It is unclear whether such variations are due to globalisation, regardless of nationality, whether omnivorousness is indeed a peculiar feature of the American society, or if it is only spread across some specific countries (Rimmer 2012; Prior 2013). Although its true meaning remains unclear (Atkinson 2011), nowadays it is broadly accepted that homology and omnivourism are indeed compatible (Tampubolon 2008a; Lizardo and Skiles 2012). Demonstrating the existence of cultural omnivourism based on a cross-national approach is thus not straightforward. We need to define a flexible theoretical and empirical approach that considers global and local differences within and between societies, alongside an adequate set of cultural indicators.

For the first of these, we use the concept of cultural eclecticism, broadly defined as the 'selection and combination of cultural elements belonging to domains considered different, e.g., highbrow and lowbrow' (Ollivier, Gauthier and Truong 2009: 459). This conceptualisation offers some desirable advantages which allow us to perform an appropriate analysis without jeopardizing the strength of our cross-national comparison. Cultural omnivorism as commonly defined by Peterson, and research directly influenced by his oeuvre, feature individuals from higher social positions; this implies highbrow taste and also assumes that lower classes are passive to culture (Peterson 2005; Lahire 2008). These peculiarities make it difficult to search for cultural omnivores under a comparative perspective. Eclectics are individuals who can move across boundaries defined in terms of omnivourism, and also as loose-boundedness (Lamont 1992), and according to modes of openness to cultural diversity (Ollivier 2008). Taste omnivourism therefore - commonly defined as a feature of individuals from higher social positions, implying highbrow taste (Peterson 2005) -is here understood as a special case of eclecticism.

\section{Intensity of musical judgement}

For Bourdieu (1984), music plays a central role as one of the most important social markers. Moreover, music is a cultural domain where everybody has an opinion and cultural boundaries are drawn and subsequently redrawn (Tampubolon 2008a). Conceptual tools such as musical genres allow the detection of communities' perspectives of musical styles. However, agreement exists in that it is not possible to explain all forms of inequality through a single cultural hierarchy (Erickson 1996). Aware of this limitation, we can justify the decision to analyse indicators of musical taste for two reasons. Firstly, music is a cultural activity, part of everyday life and central to social research, where it is possible to detect strong tensions between popular and consecrated forms (Frith 1996; Bennett et al 2009). Secondly, several studies confirm that musical taste and consumption is a domain where it is still possible to visualise social tensions which relate to, among others, age, class and education, allowing comparability and confirming our selection (Chan and Goldthorpe 2007; Katz-Gerro, Raz and Yaish 2007; Tampubolon 2008b; Bennett et al 2009; Cvetičanin and Popescu 2011; Binder 2012).

A major weakness of studies in this area is that music (like any other cultural domain) is not equally important to all people. A difference with other art forms is that music relies heavily on trends, market characteristics and internal and external influences (Wright 2011), making it important to consider the specific contexts in which people understand culture. In this regard, Frith (1996) claims that the individual's evaluation of musical genres is based on a range of discursive practices which have evolved over time. Broadly speaking, the author's three defined judgmental discourses recognize that similarly as taste for highbrow music is a reflection of class, engagement with rare and exclusive popular music produces symbolic profit (Prior 2013). Art discourse is where music provides a transcendent experience available only to people with certain abilities. Folk discourse values music as a cultural necessity with little or no separation of art and life, and emphasises its role as a means of placement. In Popular discourse, values are created by and organised around the music industry and music events geared towards emotional gratification. These concepts have been used to contextualise musical taste groups (van Eijck 2001; Ollivier 2008), but never for comparative purposes.

We argue that it is possible to extend Frith's (1996) framework to provide us with a solid theoretical basis from which to understand combinations of musical preferences, flexible enough to generalise to every local music scene, and which at the same time captures several locally-defined stratification axes. In consequence, if eclecticism does exist, we suggest it occurs at the intersection of these three discourses. Its meaning within social structures varies according to national economic, social and historical contexts; it is capable however of crossing some - if not all - country-specific boundaries as defined by other taste groups.

\section{Cultural research: a cross-national perspective}

4.1 To justify the relevance of our country selection, we consider pertinent to briefly review the main features of their historical and cultural national repertoires. Firstly, although these countries played diverse political roles during the twentieth century, today they are all democratic regimes and have capitalist economies. Contemporary Austria is a small republic defined by its constitution as perpetually neutral. Its society is highly homogeneous in ethnic and religious composition, with a developed market economy and broad welfare state that does not redistribute income. Post-second world war, England rebuilt itself into a modern European nation to become a 
leading trading power and financial centre. However, the current right-wing government has exponentially restricted the growth of social welfare programmes. Under a communist regime for forty-five years, after ten years of a nationalistic-influenced government, the economy of contemporary Serbia is mainly dominated by market forces, with a large state sector and a reformed (but not sufficiently strong) welfare state. Created in 1947, the State of Israel is marked by migratory patterns and deep tensions with neighbouring Arab countries, both of which define its ethnic and religious divisions. Israel has a technologically-advanced market economy and a comprehensive welfare state.

Secondly, the selected national musical scenes espouse different combinations of foreign cultural influences. Austria has a significant musical legacy: in addition to preserving a strong folk tradition, it is considered by many to be the European capital of western classical music. However, tensions exist here between supporters of traditional folk, schlager and volkstumliche folk-pop ballads, American- and Britishinfluenced rock and hip-hop, and hybrid world music (Reitsamer 2012). England features widely in the literature on culture and social stratification. Nowadays, tensions are evident between young people with a preference for popular emerging styles such as urban music, as opposed to the more traditional tastes of country and western, world music, and classical of the more adult population (Savage 2006; Savage and Gayo 2011). Israel has been greatly influenced by its international diaspora, religious traditions and musical forms. Songs of the land of Israel (broadly recognised as mainstream folk music) and western-influenced pop/rock are massively popular in Israel (Regev 2000). However, Middle Eastern music, originating from the Arab and Islamic musical traditions, has been largely excluded from the local music mainstream (Regev 2000). Despite the fact Serbia was until 1990 part of a communist state, it has maintained its highly diverse and popular folk expressions mixed with the latest global music. Historically, old-town folk, ancient musical expressions, and traditional folk are highly popular among Serbians, alongside rock and dance music (Cvetičanin 2008). During the 1990s in Serbia, rock took a critical stance against the post-socialist regime (Mijatovic 2008), while dance evolved into turbo-folk (electronic music with its roots in folk), emulating the lifestyle of the nineties new elite (Kronja 2004).

4.3 In summary, these political, economic, and cultural differences make our cross-national comparison appealing as a means to test the existence of broader musical taste patterns.

\section{Aims and research questions}

5.1 This article provides a detailed analysis of Austrian, English, Israeli and Serbian musical taste, the first time such comparison is being made. Specifically, we focus our efforts on answering four research questions:

1. Is it possible to detect groups of musical preferences across our sample of countries?Previous research has already explained how political, economic and cultural differences go some way to explaining the symbolic differentiation reflected by cultural consumption in Austria (Binder 2012); England (Tampubolon 2008b; Warde and Gayo-Cal 2009; Savage and Gayo 2011), Israel (Yaish and Katz-Gerro 2012) and Serbia (Cvetičanin and Popescu 2011). Based on a flexible theoretical and empirical approach this research offers a robust test of whether musical preferences can be grouped into a finite number of patterns.

2. How are they composed in terms of musical likes and dislikes and how are they structured across several axes of social stratification? Intensity and meaning given to musical genres is best understood within each cultural context, as the circumstances in which these judgments are framed may differ. The discourses of Frith (1996) provide conceptual support to help identify patterns of musical like and dislike. Cross-national research in each area thus needs to take into consideration the tensions and particularities of each national musical scene.

3. Is musical eclecticism a feature spread across different societies?This research understands musical taste as a dynamic phenomenon across countries, and we therefore suggest the use of the alternative term cultural eclectic, which provides an overview within which to detect those taste and distaste groups which cut across cultural boundaries. Analysing gradational scales of measurement, taste and distaste groups are tested to see whether they are culturally open. In order to acknowledge the significance of the combinatorial nature of the judgments made by respondents, we argue that cultural boundaries are built not only when one group expresses extreme dislike and another expresses extreme like of one or more particular genres (Savage 2006; Tampubolon 2008a) but also when within each group intermediate or neutral preferences are expressed.

4. Are Austrian, English, Israeli and Serbian eclectics holders of higher social positions? Do they differ in terms of sociodemographic characteristics? Despite warnings against the risk of socioeconomic reductionism of relating taste to social position (Hanquinet 2013) and the fact that taste today is less defined in terms of social class (Bennett et al 2009), we are interested in testing under our comparative approach if any of omnivorousness operationalisations (volume, composition or both), commonly defined as a feature of individuals from higher social positions (Peterson 2005) are possible to detect across our sampled countries. And moreover, we focus on potential changes across countries in the shape and intensity of the relationship between social positions and taste patterns.

\section{Data and method}

6.1 This section introduces the data used in this research, our statistical modelling strategy and our method of missing data imputation. Special emphasis is given to the integration of the theoretical aspects mentioned above. 
Data

6.2 The data used for this research comes from a number of national studies that have been specifically designed to enable the study of cultural consumption; the first part of Table 1 summarises their main features. The data has similar levels of representation, favouring comparisons across countries. However, it was collected over a five-year period (2003-2008), making it impossible to control for differences relating to variations in music markets over time, such as trends or new popular genres.

Table 1. Data sources and stratifying variables.

\begin{tabular}{|c|c|c|c|c|c|}
\hline & & Austria $^{1}$ & England $^{2}$ & Israel $^{3}$ & Serbia $^{4}$ \\
\hline & Source & $\begin{array}{l}\text { Project Wozu } \\
\text { Musik? } \\
\text { (Music, what } \\
\text { for?) }\end{array}$ & $\begin{array}{l}\text { Project } \\
\text { Cuitural } \\
\text { capital and } \\
\text { social } \\
\text { exclusion }\end{array}$ & $\begin{array}{l}\text { Cultural } \\
\text { consumption } \\
\text { survey }\end{array}$ & $\begin{array}{c}\text { Project } \\
\text { Cultural } \\
\text { Needs, Habits } \\
\text { and Taste of } \\
\text { Citizens of } \\
\text { Serbia and } \\
\text { Macedonia }\end{array}$ \\
\hline & Year & 2008 & 2003 & 2007 & 2005 \\
\hline & Sample gize & 1004 & 1279 & 1005 & 1364 \\
\hline & Representativeness & $\begin{array}{c}\text { Austrian } \\
\text { population }\end{array}$ & $\begin{array}{l}\text { Adults living } \\
\text { in private } \\
\text { households in } \\
\text { England }\end{array}$ & $\begin{array}{l}\text { Israeli Jewish } \\
\text { population }\end{array}$ & $\begin{array}{l}\text { Population of } \\
\text { legal age } \\
\text { from } \\
\text { Republic of } \\
\text { Serbia }\end{array}$ \\
\hline & Covariates & & Perce & ntage & \\
\hline & 18 to 35 & 30.3 & 28.0 & 32.9 & 38.6 \\
\hline & 36 to 50 & 31.1 & 28.7 & 28.9 & 29.7 \\
\hline ige (yedry) & Over 50 & 38.6 & 43.1 & 36.2 & 31.7 \\
\hline & Mussing & 0 & 0.2 & 2.0 & 0 \\
\hline & Male & 47.1 & 44.9 & 43.3 & 45.7 \\
\hline Gender & Female & 52.9 & 55.1 & 56.7 & 53.8 \\
\hline & Missing & 0 & 0 & 0 & 0.5 \\
\hline & $\begin{array}{c}\text { Labour } \\
\text { contract } \\
\text { P.bourgeoisie }\end{array}$ & 22.0 & 32.6 & 16.7 & 47.4 \\
\hline $\begin{array}{l}\text { Occupational } \\
\text { class }\end{array}$ & $\stackrel{+}{+}$ & 51.4 & 31.6 & 35.9 & 33.1 \\
\hline & Service & 16.0 & 33.5 & 33.9 & 17.8 \\
\hline & Missing & 10.6 & 2.3 & 13.5 & 1.7 \\
\hline & ISCED 1-2 & 15.6 & 28.7 & 17.2 & 13.6 \\
\hline Education & ISCED 3 & 72.2 & 36.0 & 47.2 & 56.5 \\
\hline & ISCED 4-6 & 12.2 & 33.9 & 34.5 & 27.3 \\
\hline & Missing & 0 & 1.4 & 1.1 & 2.6 \\
\hline Nationality & & $\begin{array}{c}\text { Bom in } \\
\text { Austria: } 88.6 \\
\text { Not borm in } \\
\text { Austria: } 11.1 \\
\text { Missing: } 0.3\end{array}$ & NA & NA & $\begin{array}{c}\text { Serbian: } 87.0 \\
\text { Non Serbian: } \\
11.2 \\
\text { Missing:1.8 }\end{array}$ \\
\hline & & & $\begin{array}{c}\text { English } \\
\text { white: } 85.5\end{array}$ & $\begin{array}{l}\text { Sefaredi: } \\
30.7 \\
\text { Adkenazi: }\end{array}$ & \\
\hline
\end{tabular}




\begin{tabular}{|c|c|c|c|c|c|}
\hline Ethnicity & & NA & $\begin{array}{l}\text { Other ethnic } \\
\text { group: } 14.3 \\
\text { Missing: } 0.2\end{array}$ & $\begin{array}{c}42.4 \\
\text { Israeli: } 22.0 \\
\text { Other: } 1.3 \\
\text { Missing: } 3.6\end{array}$ & $\mathrm{NA}$ \\
\hline $\begin{array}{l}\text { Place of } \\
\text { residence }\end{array}$ & Missing & $\begin{array}{c}\text { North (incl } \\
\text { Vienna): } 55.8 \\
\text { Rest of the } \\
\text { country: } 44.2 \\
0\end{array}$ & $\begin{array}{l}\text { London: } 24.5 \\
\text { Rest of the } \\
\text { country: } 75.5 \\
0\end{array}$ & $\begin{array}{c}\text { Large city } \\
(>200.000): \\
28.6 \\
\text { Rest of the } \\
\text { country: } 71.4 \\
3.6\end{array}$ & NA \\
\hline
\end{tabular}

1:Hubber (2009), 2:Thomson (2004). Only English subsample, 3:Yaish and Katz-Gerro (2012), 4:CvetiČanin (2008). Only Serbian subsample.

Explanatory variables in the models have been recoded into comparable categories to broadly illustrate how stratification axes across countries explain overall trends, and to speed up statistical modelling. Age in years was recoded in three wide categories to broadly illustrate tension among youth-middle-adult age groups comparable across countries. Occupational class roughly corresponds with Erickson and Goldthorpe's four-class schema (Breen 2005) and due to low frequency, petty bourgeoisie was merged with intermediate. Educational levels correspond with the International Standard Classification of Education (ISCED) (UNESCO 2012)[2]. It has only been possible to include a self-declared ethnicity variable when examining England and Israel. Austria and Serbia are the only countries that provide information about the respondent's nationality. For place of residence, we include a dichotomic variable for Austria and England (whether the respondent lives in the capital or the rest of the country); for Israel the only information available is city size, and no such information is available for Serbia. The second part of Table 1 provides a summary of the explanatory variables, their categories and frequencies.

Table 2. Measurement scales of musical indicators. In brackets:Percentage of don't know and have not heard of.

\begin{tabular}{|c|c|c|c|c|}
\hline & Austria & England & Israel & Serbia \\
\hline $\begin{array}{l}\text { Scale of } \\
\text { measurement }\end{array}$ & $\begin{array}{l}\text { 7-points like to } \\
\text { dislike }\end{array}$ & $\begin{array}{l}\text { 7-points like to } \\
\text { dislike }\end{array}$ & $\begin{array}{l}\text { 5-points like to } \\
\text { dislike }\end{array}$ & $\begin{array}{l}\text { 5-points like to } \\
\text { dislike }\end{array}$ \\
\hline \multirow[t]{5}{*}{$\begin{array}{l}\text { Common } \\
\text { genres }\end{array}$} & $\begin{array}{l}\text { Rock music out of } \\
\text { the charts }(2.6 \%)\end{array}$ & $\begin{array}{l}\text { Rock, including } \\
\text { indie }(4.1 \%)\end{array}$ & Rock $(2.8 \%)$ & Rock/pop (3.2\%) \\
\hline & Classical $(2.9 \%)$ & $\begin{array}{l}\text { Classical, incl. } \\
\text { opera }(0.4 \%)\end{array}$ & Classical (1.5\%) & Classical (1.0\%) \\
\hline & Jazz $(0.6 \%)$ & $\begin{array}{l}\text { Modern jazz } \\
(0.8 \%)\end{array}$ & $\begin{array}{l}\text { Blues and jazz } \\
(3.0 \%)\end{array}$ & $\begin{array}{l}\text { Blues and jazz } \\
(2.6 \%)\end{array}$ \\
\hline & $\begin{array}{l}\text { Hip-hop/black } \\
\text { music }(12.0 \%)\end{array}$ & $\begin{array}{l}\text { Urban,incl. Hip- } \\
\text { hop and R\&B } \\
(5.8 \%)\end{array}$ & Hip-hop (8.0\%) & $\begin{array}{l}\text { Rap/hip-hop } \\
(15.2 \%)\end{array}$ \\
\hline & $\begin{array}{l}\text { Techno/house } \\
(14.4 \%)\end{array}$ & $\begin{array}{l}\text { Electronic dance } \\
\text { music incl. techno } \\
\text { and house }(8.3 \%)\end{array}$ & Dance $(4.6 \%)$ & $\begin{array}{l}\text { Dance/house } \\
(13.4 \%)\end{array}$ \\
\hline \multirow[t]{3}{*}{$\begin{array}{l}\text { Country } \\
\text { specific } \\
\text { genres }\end{array}$} & $\begin{array}{l}\text { Traditional } \\
\text { Austrian folk } \\
(1.2 \%)\end{array}$ & $\begin{array}{l}\text { World music,incl. } \\
\text { reggae and } \\
\text { bhangra }(2.7 \%)\end{array}$ & $\begin{array}{l}\text { Songs of the land } \\
\text { of Israel }(1.7 \%)\end{array}$ & $\begin{array}{l}\text { 'Old-town' folk } \\
(0.3 \%)\end{array}$ \\
\hline & $\begin{array}{l}\text { World music } \\
(21.2 \%)\end{array}$ & $\begin{array}{l}\text { Country and } \\
\text { western }(0.6 \%)\end{array}$ & $\begin{array}{l}\text { Hebrew music } \\
(2.4 \%)\end{array}$ & $\begin{array}{l}\text { Traditional folk } \\
\text { music }(0.4 \%)\end{array}$ \\
\hline & $\begin{array}{l}\text { Volkstumliche/ } \\
\text { schlager }(0.9 \%)\end{array}$ & $\begin{array}{l}\text { Heavy metal } \\
(2.6 \%)\end{array}$ & $\begin{array}{l}\text { Middle Eastern } \\
\text { music }(1.4 \%) \\
\text { Religious music } \\
(1.5 \%)\end{array}$ & Turbofolk (2.4\%) \\
\hline
\end{tabular}

Table 2 presents the musical genres used for each country. In order to include the largest amount of data possible, the residual 'do not know' category has been recoded in the midpoint of the scale and should be considered as neutral. Although response frequencies for most genres analysed are not higher than $5 \%$, the decision about how to deal with them is not a trivial one and during preliminary phases of data analysis we tried several options to deal with them: cases were reassigned to the most frequent category, excluded from analysis, treated as imputed missing values and recoded in the midpoint as neutral. Our exploration suggested that results are robust regardless of which alternative is used. approximate to the most frequently-occurring musical indicators analysed in the literature (rock, classical, jazz, hip-hop/urban and electronic). As noted in Table 2, labels are not identical, but roughly comparable across countries and against previous research. We also include three or four country-specific genres. As mentioned above, these belong to folk and popular styles that reflect local cultural tensions and complement the characterisation of each musical domain. 
This article utilises a latent class model with covariates, known as the latent class MIMIC model (Skrondal and Rabe-Hesketh 2004). The advantage of this approach is that we can test whether observed musical tastes and distastes indicators can be grouped in specific patterns or latent classes, and at the same time quantify the impact of a set of explanatory variables pertaining to the construction of classes, avoiding bias produced when classification and explanatory variables of groups are performed in separate steps (Vermunt and Magidson 2008). This statistical method has been shown to be adequate for understanding the association between culture and social structure, proving to be a refined tool based on a probabilistic framework from latent variable modelling (Tampubolon 2008a, Leguina 2015).

A MIMIC latent class model assumes that each observation belongs to one of $t=1, \ldots, s$, T unknown and unobserved (latent) classes. The probability that a respondent (Yi) displays a specific pattern of musical taste and distaste conditional to $q=1, \ldots, Q$ explanatory variables $\mathbf{Z} i$ is

$$
P\left(\boldsymbol{Y}_{i} \mid \boldsymbol{Z}_{i}\right)=\sum_{t=1}^{T} P\left(\boldsymbol{Y}_{i} \mid X=t\right) P\left(X=t \mid \boldsymbol{Z}_{i}\right)
$$

where the first part of the model, called measurement model

$$
P\left(\boldsymbol{Y}_{i} \mid T=t\right)=\prod_{k=1}^{K} P\left(Y_{i k} \mid T=t\right)=\prod_{k=1}^{K} \prod_{r=1}^{R_{k}} \theta_{k t r}^{I\left(Y_{i k}=r\right)}
$$

corresponds to the measurement model (specified as unrestricted latent class analysis), with $\mathrm{k}=1, \ldots, \mathrm{K}$ number of musical genres, $\mathrm{r}=1, \ldots, \mathrm{Rk}$ is the specific answer to $\mathrm{k}$ genre and $\mathrm{I}(\mathrm{Y} i \mathrm{k}=\mathrm{r}$ takes the value of 1 if observation i displays taste level $r$ to genre $k$ and 0 otherwise. The output of this submodel is the probability of displaying specific patterns of tastes and distastes given the belonging to a specific taste and distaste group. The second part (structural model) is defined as follows:

$$
P\left(X=t \mid Z_{i}\right)=\frac{\exp \left(\gamma_{0 \mathrm{t}}+\sum_{\mathrm{q}=1}^{\mathrm{Q}} \gamma_{\mathrm{qt}} \mathrm{z}_{\mathrm{iq}}\right)}{\sum_{s=1}^{T} \exp \left(\gamma_{0 \mathrm{t},}+\sum_{\mathrm{q}=1}^{\mathrm{Q}} \gamma_{\mathrm{qs}} \mathrm{z}_{\mathrm{iq}}\right)}
$$

Where $y$ represents the parameters of the structural model derived from multinomial logistic regression. This part of the model quantifies the impact of stratifying variables over taste and distaste groups found. The software used to fit the proposed model is Latent GOLD 4.5 (Vermunt and Magidson 2008).

6.9 In order to minimise any loss of information, multiple imputation is performed (Rubin 1987; Vermunt, Van Ginkel, Van der Ark and Sijtsma 2008). A highly important methodological challenge of this kind of complex model is the sparseness of data. The standard maximum likelihood (ML) estimation procedure is problematic as estimated parameters might be highly biased or even converge to infinity (Galindo-Garre and Vermunt 2006). Therefore, the complexity of those models with ordinal indicators forces us to go one step further, using an alternative estimation method called maximum a posteriori estimation ${ }^{[3]}$ which prevents the obtaining of boundary solutions. Sensitivity tests under different configurations demonstrated that this approach makes it possible to obtain reliable insights into overall patterns of musical taste, with the information available and without compromising our proposed theoretical approach.

\section{Results}

7.1 To select the final model for each country we used the lowest Bayesian information criterion (BIC) [4], lowest percentage of misclassification, moderate bivariate residuals, and ease of interpretation (Formann 2003; De Menezes and Lasaosa 2007; Vermunt and Magidson 2008). Due to scarcity of space, Table3 summarises only the first and second criteria. Fitting models independently for each country, these criteria lead us to select in every case a five-cluster or class solution. After finding the optimal number of groups, individuals are assigned to the class with the highest probability of belongingness (at least 0.5 ). 


\begin{tabular}{ccccc}
\hline & \# clusters & BIC & DF & $\begin{array}{c}\text { Class. } \\
\text { Error }\end{array}$ \\
\hline Austria & 4 & 27046.439 & 889 & 0.130 \\
& $\mathbf{5}$ & $\mathbf{2 7 0 3 4 . 4 8 5}$ & $\mathbf{8 8 1}$ & $\mathbf{0 . 1 6 4}$ \\
& 6 & 27046.052 & 863 & 0.171 \\
\hline \multirow{2}{*}{ England } & 4 & 34675.914 & 1174 & 0.125 \\
& $\mathbf{5}$ & $\mathbf{3 4 6 1 7 . 7 0 7}$ & $\mathbf{1 1 5 6}$ & $\mathbf{0 . 1 3 2}$ \\
& 6 & 34615.139 & 1138 & 0.151 \\
\hline \multirow{2}{*}{ Israel } & 4 & 26063.912 & 901 & 0.165 \\
& $\mathbf{5}$ & $\mathbf{2 6 0 4 0 . 8 1 3}$ & $\mathbf{8 8 0}$ & $\mathbf{0 . 1 6 7}$ \\
& 6 & 26065.675 & 859 & 0.163 \\
\hline \multirow{2}{*}{ Serbia } & 4 & 28367.841 & 1274 & 0.108 \\
& $\mathbf{5}$ & $\mathbf{2 8 2 3 0 . 3 3 5}$ & $\mathbf{1 2 5 7}$ & $\mathbf{0 . 1 3 7}$ \\
& 6 & 28280.618 & 1240 & 0.138 \\
\hline
\end{tabular}

Identifying taste and distaste groups: comparative analysis

7.2 To understand the composition of latent classes and to reduce the amount of data presented, figures 1 to 5 summarise for each taste group their conditional probabilities of displaying a specific preference level for each genre. Classes are not defined a priori and outcomes for taste groups are thus interpreted according to how likely it is that member's judge each genre in a particular way. These are free to vary across countries, reflecting different music indicators used for each model and national repertoires part of our analysis.
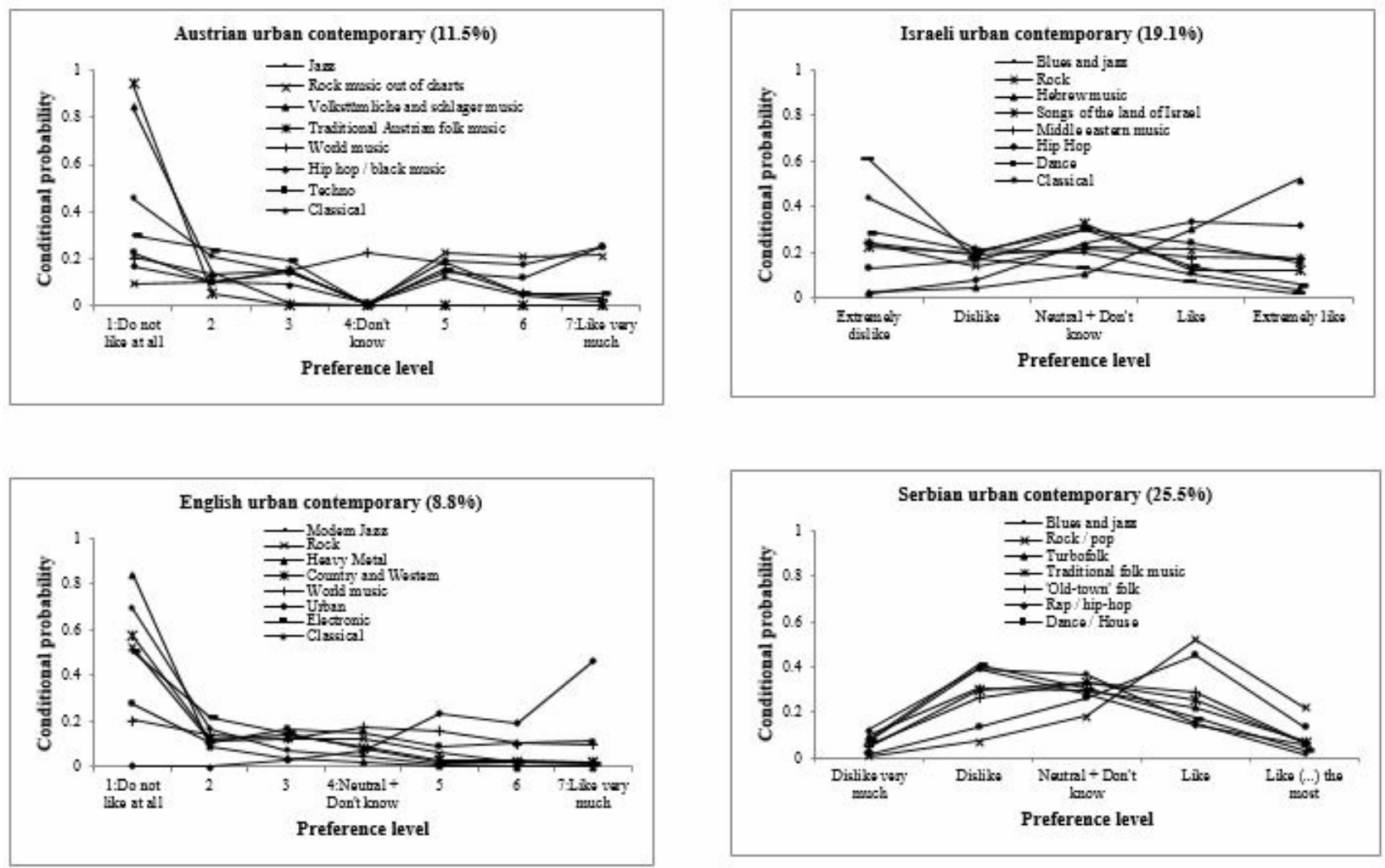

Figure 1. Pattern of preferences: Urban contemporary. 

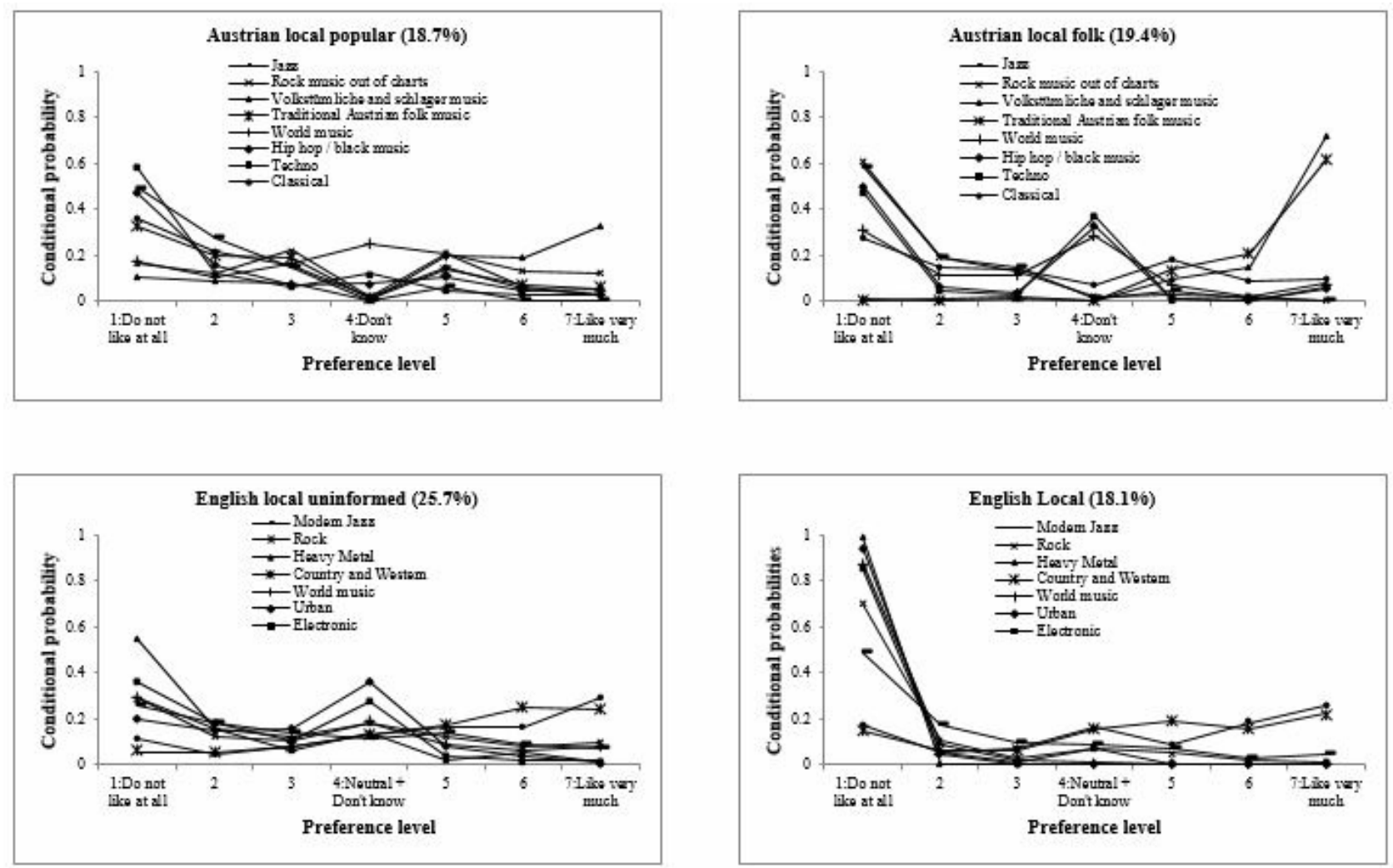

Figure 2. Pattern of preferences: Local.
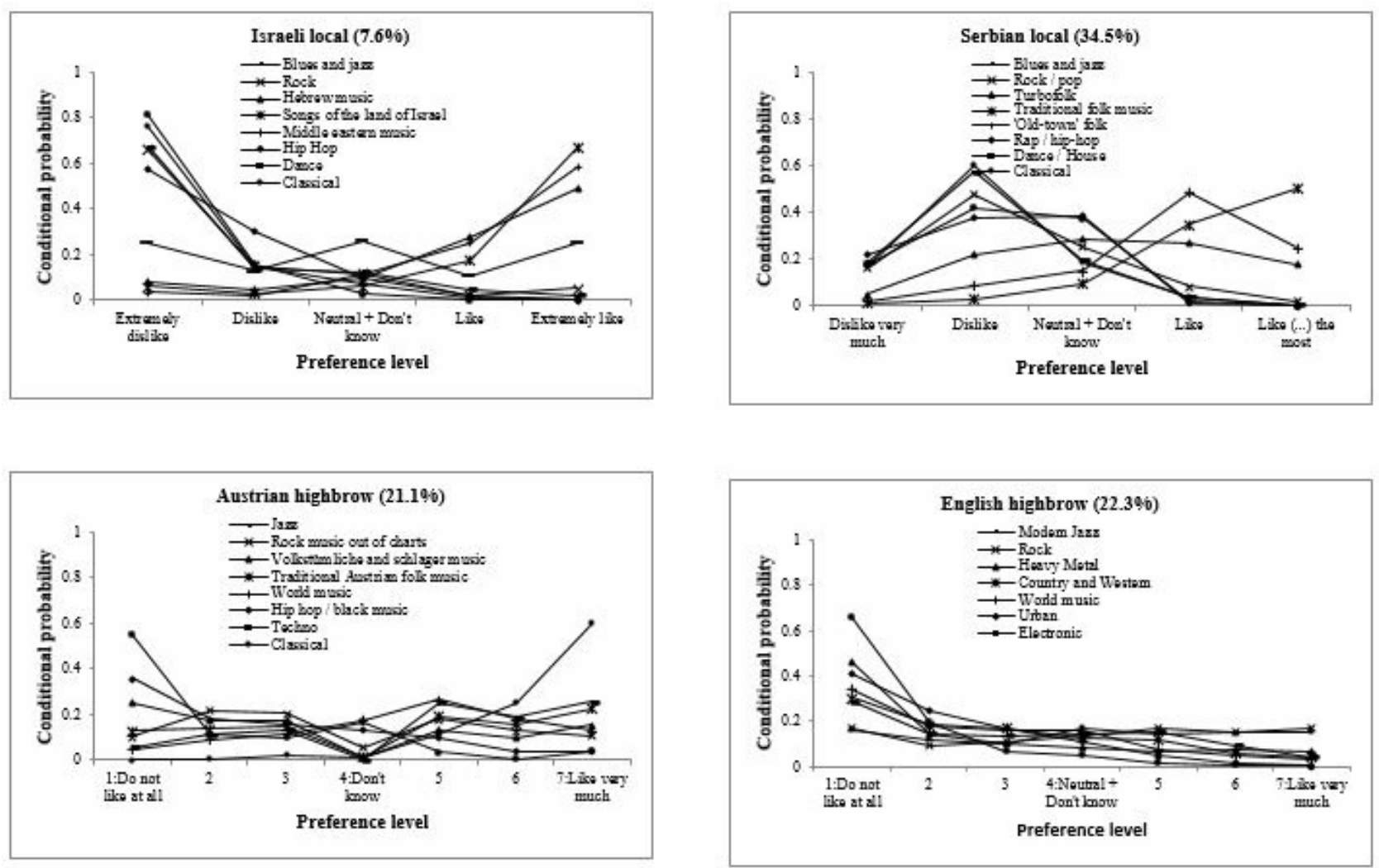

Figure 3. Pattern of preferences: Local and highbrow. 

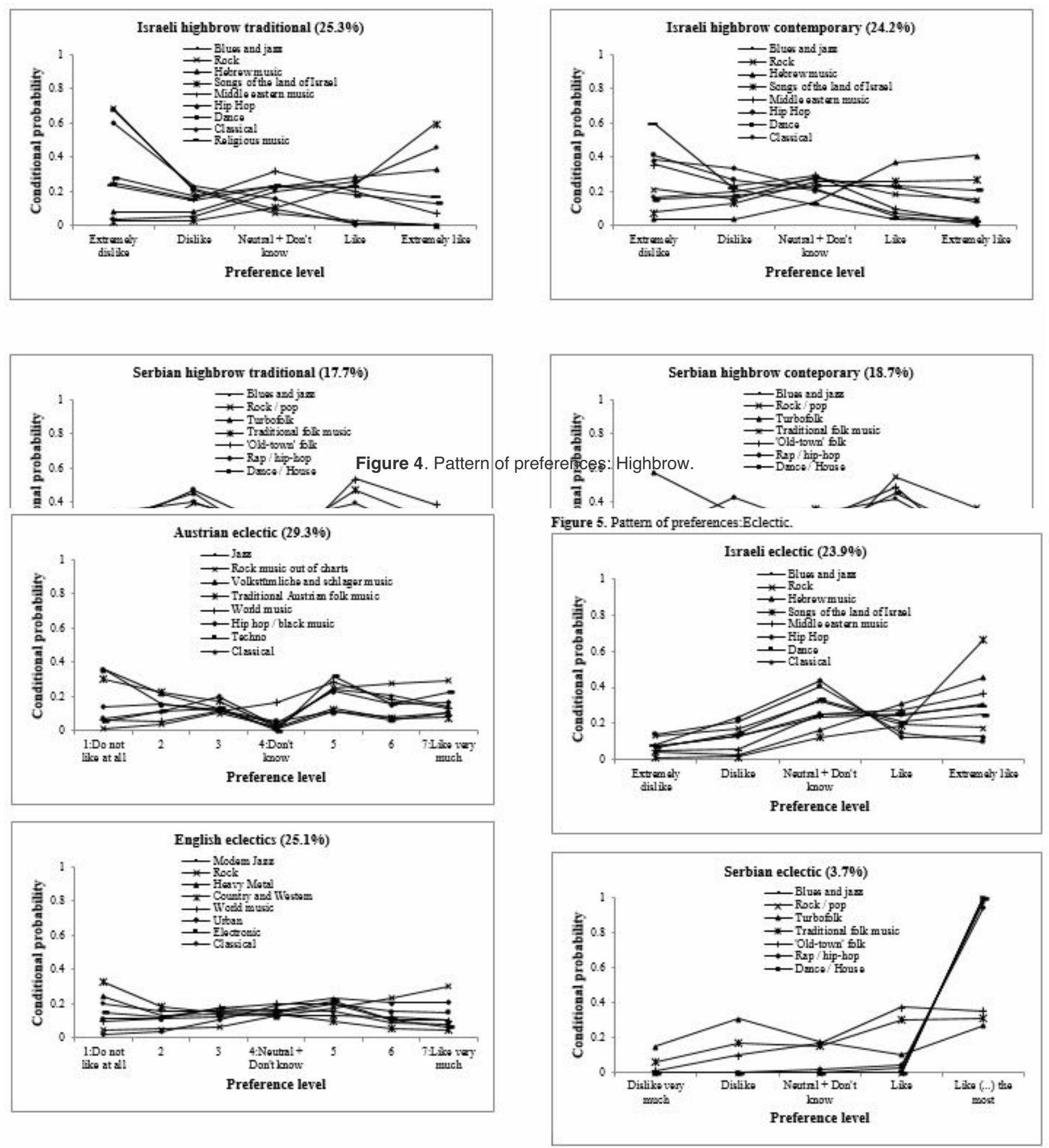

Figure 5. Pattern of preferences: Eclectic.

7.3 Across all four countries we find the highly distinctive urban contemporary group. Members tend to

display intense like of contemporary popular music, mainly such globally-known music genres as electronic, hip-

hop and rock (all part of Frith's Popular discourse). In Austria, England and Israel, members of the urban contemporary group tend to voice extreme dislike of folk music, jazz and classical music; the Serbian urban contemporary group expresses dislike of hip-hop and a positive opinion of folk music.

\section{A second major group reveals a strong preference for local music. Here, as expected, cross-country}

differences emerge. Austrian local folk groups and the Israeli and Serbian local groups voice a strong like of traditional folk music and dislike of popular, jazz music and classical (except in Austria, where members of this group appear tolerant of classical music). The Israeli local group is the smallest group of music fans in the country; in Serbia however, the local group is the largest, and declares strong like of all local genres and dislike of all other categories of music in the survey, highlighting the popularity of Serbian folk (Cvetičanin and Popescu 2011). In Austria we found internal division and identified a subset of the local grouplocal popular music.

Members of this group demonstrate a preference towards folk-rooted popular schlager and distaste for traditional folk and classical. In England, the most notable difference among local groups is the existence of two subgroups, divided in terms of levels of neutral and 'don't know' answers. Both groups display a strong like of both country and western and classical music. However, the local uninformed group has higher overall levels of intermediate opinions and 'don't know' answers compared to the local group. Moreover, this group is the largest in England, 
accounting for about a quarter of the total sample. Despite internal division, taste for locally produced music with folk roots in all four countries might be related with folk discourse and are clearly distinguished from urban contemporaries and other taste groups.

Our next taste groups are labelled as highbrow. We are aware this is a term open to discussion, and one which could be considered either subjective, or too broad, or both. However, we believe its use is justifiable, in that this taste pattern consists of genres accepted as highbrow in each country such as jazz and classical (Binder 2012; Tampubolon 2008b; Yaish and Katz-Gerro 2012; CvetiČanin and Popescu 2011), along with rock and some local styles. These are genres which appear to be compatible to those outlined in Frith's Art discourse. Austrian and English highbrows show intense dislike of the chart music that urban contemporary groups prefer. In Austria, this group also rejects volkstümliche/schlager, hip-hop and techno, while the English highbrow group dislikes electronic, urban, country and western and world music, but has the lowest levels of distaste for heavy metal. Israeli and Serbian highbrows are subdivided into those oriented to contemporary and traditional styles. In Israel, contemporary highbrows show a dislike for Israeli religious music and are neutral to classical and rock, while the traditional highbrows dislike jazz and rock and are neutral to religious music. In Serbia, both contemporary and traditional highbrows show strong dislike of turbo-folk and strongly like folk and classical. However, members of the highbrow contemporary group distinguish themselves by their taste for rock/pop and blues/jazz. Again, highbrow groups reaffirm cultural boundaries with local and urban contemporary taste groups.

\section{Eclectics and social differentiation}

In all four countries we find a group that tends to display broad taste. However, as will be shown, only Israeli and Serbian eclectics seem to behave according to traditional definitions of cultural omnivores. Moreover, it is important to notice that tepid likes and dislikes (and even neutral opinions) are not absent among omnivoreoriented groups in these countries. Table 4 summarizes patterns of preferences for eclectics in each country, highlighting the genres liked and disliked by the majority (at least 50\%) of group members in descending order.

In Austria, the only genre liked highly by eclectics is rock music; in terms of intermediate levels of taste, about fifty per cent of this group express a less intensive like of jazz, classical, world music, and hip-hop. Other genres (such as volkstümliche/schlager, traditional folk and techno) are strongly disliked among Austrian eclectics, culturally distinguishing them from local and contemporary urban groups. They therefore appear to cross some symbolic boundaries, but at the same time to reinforce and identify themselves as listeners of global taste (with the exception of techno), rejecting musical genres with local roots. It is noteworthy that this is the biggest taste group in Austria. These findings concur with Binder (2012), who expresses scepticism of the existence of musical omnivores in Austria. English eclectics on the other hand display a stronger like of rock and urban, while their preferences towards world music, jazz, and classical music are rather tepid. Interestingly, this group has high levels of acceptance of heavy metal. Previous work has confirmed the existence of several patterns of musical omnivourism in the UK (Chan and Goldthorpe 2007, Tampubolon 2008b; Warde and GayoCal 2009; Savage and Gayo 2011). However, detected patterns of likes and dislikes show that eclectics in England are able to cross boundaries drawn by urban contemporary and highbrow groups but not those set by local groups. The lack of clearer strong preferences makes it impossible to relate this group to any of the traditional definitions of omnivourism.

Table 4. Eclectic group preferences sorted by conditional probabilities (descending order)

\begin{tabular}{|c|c|c|c|c|}
\hline $\begin{array}{c}\text { Eclectics } \\
\text { (sample \%) }\end{array}$ & Austrian (29.3) & English (25.1) & Israeli (23.9) & Serbian (3.7) \\
\hline \multirow{7}{*}{$\begin{array}{c}\text { Liked by the } \\
\text { majority }\end{array}$} & $\begin{array}{l}\text { Rock music out } \\
\text { of charts }\end{array}$ & Rock & $\begin{array}{l}\text { Songs of the } \\
\text { land of I. }\end{array}$ & Blues and jazz \\
\hline & $\mathrm{Jazz}$ & Urban & Hebrew music & Rock/pop \\
\hline & World music & Electronic & Middle eastern & Dance / House \\
\hline & Classical & & Classical & Classical \\
\hline & $\begin{array}{c}\text { Hip hop / black } \\
\text { music }\end{array}$ & & Religious music & Rap / hip-hop \\
\hline & & & & 'Old-town' folk \\
\hline & & & & $\begin{array}{c}\text { Traditional folk } \\
\text { music }\end{array}$ \\
\hline \multirow{4}{*}{$\begin{array}{l}\text { Disliked by } \\
\text { the majority }\end{array}$} & Volkstümliche & Country and & & \\
\hline & and schlager & Western & & \\
\hline & Austrian folk & & & \\
\hline & Techno & & & \\
\hline
\end{tabular}

Consistent with previous research, we recognise the existence of omnivourism in Israel (Yaish and KatzGerro 2012). Israeli eclectics share certain tastes with highbrow and local groups, however, they also express a considerable frequency of neutral opinion in regard to a wide variety of global musical styles (dance, rock and hip-hop). The figures are considerably higher than the 'don't know' response (no more than $4 \%$ in every genre 
except for dance and hip-hop). Our findings therefore indicate that Israeli eclectics might behave like omnivores by composition. Serbian eclectics are the smallest taste group within Serbia and significantly small compared to other countries (3.7\% of the sample). However, this group seems to be the most consistent with the definition of omnivores in terms of volume, expressing strong taste for all musical genres except turbo-folk. This small group is the only one able to cross all symbolic boundaries of their national musical domain. CvetiČanin and Popescu (2011) propose that Serbian omnivores are internally divided. We found no other taste group in any of the four countries that appears to behave like musical omnivores.

\section{Taste and distaste groups: Who are they?}

The next step is to understand the influence of stratifying variables. In this section, we interpret results by focusing on eclectics and how they differ from other groups, with the objective of characterising eclectics in economic, social and personal terms. Where eclectics have a higher social position, we find evidence of cultural omnivourism in terms of social differentiation. For this, estimated coefficients from the structural model are interpreted (Table 5). In Austria, all variables except sex and immigration are statistically significant, with age being by far the most important explanatory variable of taste and distaste groups. Eclectic tends to be older than urban contemporary but younger than other groups. Highbrow is the only group other than eclectic who are better educated and belong to a similar occupational class. Additionally, they are over-represented in the north of the country where the capital city Vienna is located. In contrast, local and urban contemporary groups are defined by their lower educational attainment. The Austrian eclectic thus seem to hold an advantaged social position across groups, but not the highest.

Table 5. Structural model coefficients. Reference category: a: 18-35; b: ISCED 1-2; c: labour contract; d: male; e: English white; f: Sephardic; g: rest of the country; h: London; i: small/medium city; j: born in Austria; k: Serbian.

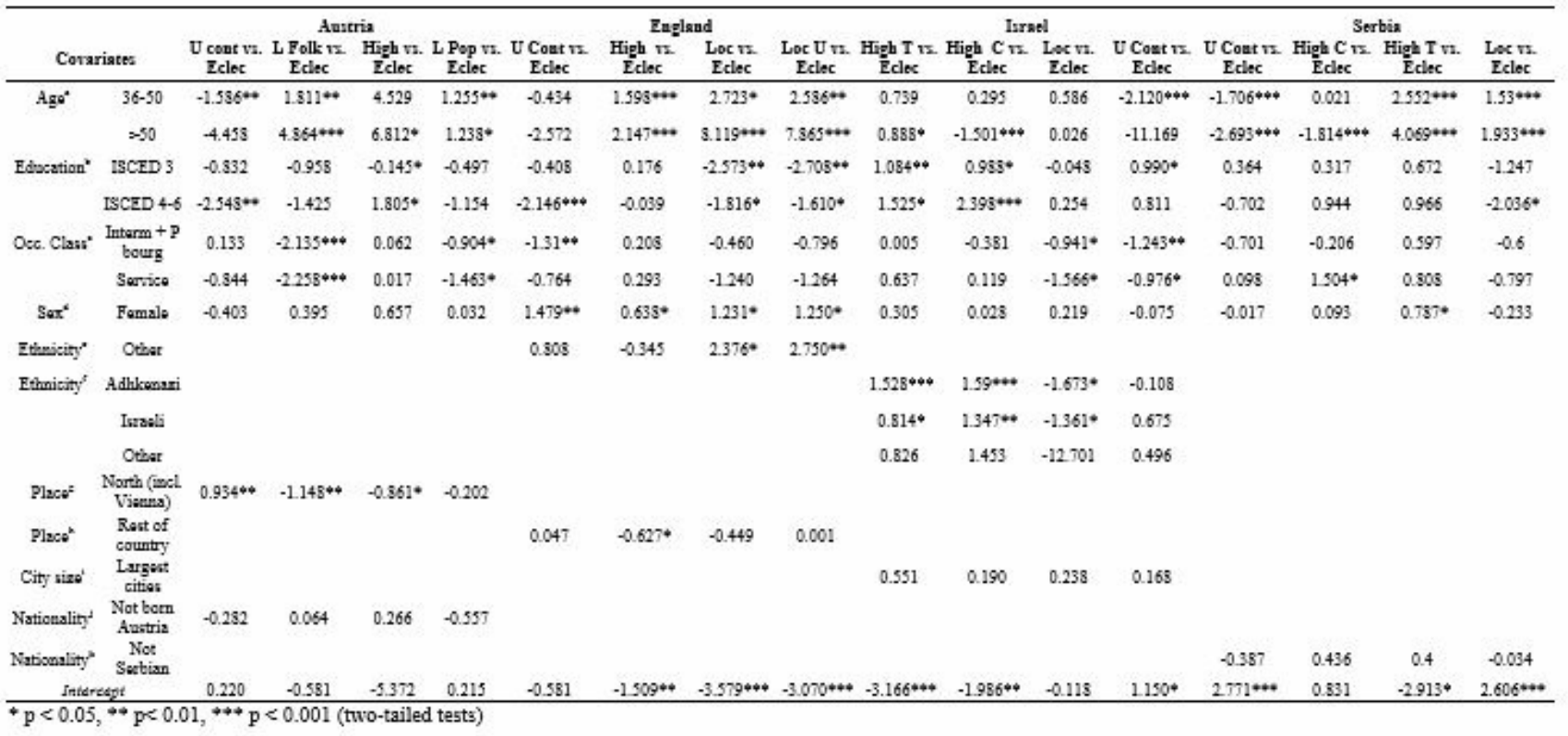

7.10 In England, all other variables except place of residence are highly statistically significant. Again, English eclectics tend to be younger thanhighbrows and local group members but older than urban contemporary, sharing a higher occupational class with the former, but being more ethnically diverse. Local groups are characterised as less educated[5], being from a lower occupational class and (in the case of the uninformed subgroup) having the highest proportion of non-white members. English eclectic and highbrow share the same social and economic advantages; however, the former tend to be younger, ethnically diverse males from London, while the latter comprise more exclusive, middle-aged whites from the rest of the country. Similarly to Austria, English eclectic is at the top of the social hierarchy, but cannot be distinguished from the highbrow taste group.

7.11 In Israel, all variables except city size and sex are statistically significant. Ethnicity, age and education are the most important explanatory variables of taste and distaste groups. In contrast to Austria and England, 
older age groups (mostly within the Sephardic Jewish community), intermediate occupational class and education are the features that define Israeli eclectics. In comparison, Israeli urban contemporary is mainly young people with no higher than secondary education and belonging to a lower occupational class. Eclectics here are not the ones with social and cultural advantages, and appear to share a social position with the local group. Both highbrow groups (contemporary and traditional) have higher levels of education and belong to higher occupational classes, and at the same time are older and mostly Ashkenazi[6]. In Serbia, all variables except nationality are statistically significant, the most important being age, education and occupational class. Individuals of a young age, highly educated but from a middle occupational class tend to display eclectic taste. Eclectics in Serbia have attained a higher educational level and belong to a higher occupational class thanurban contemporary and local groups. However, as in Israel, traditional highbrow groups (and especially contemporary highbrows) appear to be part of the national elite, displaying higher levels of educational attainment and higher occupational class.

\section{Omnivourism, distinction, and beyond: a cross-national perspective}

At a comparative level, eclectics in each country seem to share a number of features. For example, they have broad tastes but do not express a strong like for several musical styles. Although some of the detected patterns of eclecticism may fit with definitions of omnivourism by volume or composition, eclectics do not cross every cultural boundary. There is no clarity if the benevolent indifference detected in eclectic groups could be interpreted as tolerance or disdain. Moreover, it is questionable if this involves a new cultural aesthetic (Lahire 2008; Lizardo and Skilles 2012). It is not possible to establish that omnivourism represents a change of culturestructure relationship, but it does at least appear to be a different musical discursive orientation, reflecting the increased availability of and access to different cultural forms.

Furthermore, social meanings of eclecticism vary according to national stratification structure and go beyond occupational class, education and age. It is particularly striking that although eclectics in Israel and Serbia appear to display preferences similar to traditional definitions of omnivourism, they do not necessarily belong to any national elite; only English and Austrian eclectics share socially advantaged positions with other taste groups. Several taste groups with narrow preferences and strong distastes hold the most socially disadvantaged positions, but some are also advantaged. However, understanding these groups as part of more complex judgemental discourses (Frith 1996), we argue that their meaning goes beyond that conveyed by the terminology of univores as suggested by Peterson (2005). The evidence shows that eclectics try to differentiate themselves from lower groups by displaying broad tastes or at least by accepting several genres. However, the same mechanism is also used by other groups to reinforce social and economic boundaries through strong rejection of various cultural practices, a stance which concurs with Bourdieu (1984).

It is broadly recognised that Peterson's conceptualisation offers a partial explanation of the distribution of musical likes and dislikes (Lizardo and Skiles 2012; Prior 2013), but no research has proved before that omnivourism/eclecticism does not work in the same way in different social structures. Music, as every other cultural form, is a domain where national repertoires collaborate on shaping boundaries, tying musical works and artists in terms of similarities and differences to expectations from audience members. Although an interpretative tool such as Art, Folk and Popular judgemental discourses proved to be useful to provide a common ground to understand patterns of taste and distaste across countries, different local contexts provided by the history of a nation, the educational and stratification systems, mass media and cultural institutions are aspects that provide their utterly meaning (Lamont 1992; Regev 2011). These differences come to explain how symbolic boundaries are locally shaped and blurred, and how they lead to different musical distinctions across countries. Moreover, our findings suggest that musical indicators are not as stable across countries as some claimed (for instancePeterson 2005). In this regard we consider particularly pertinent to mention the influence of levels of interaction between mainstream and foreign cultural influences, and more traditional or locally produced genres.

In the case of Austria, while German-language folk and classical music represent both ends of musical hierarchies, from the early 1970s musicians adapted foreign American and English rock and pop creating hybrid genres, grouped under the Austropop label (Larkey 1992; Reitsamer 2012). Israeli-Jewish culture combines and adopts signs from over a 100 countries (Kaplan 2012). For instance, one of the most popular genres (songs of the land of Israel) combines itself Russian and Yiddish melodies with Romantic classical and French Chanson. Same as Austria, American and British rock, folk and pop, influence local music, to what is possible to include Middle-east and North-African musical forms (Regev 2000; Kaplan 2012). Due to its closeness to European mainstream, Serbian musical forms are heavily rooted in different folk styles, commonly charged with political meanings (Hudson 2003). A clear example of this is that during the 1990s, local music influenced by 'western' styles such as rock and dance music acquired opposite political and social sidewalks. While the former critiqued Slobodan Milosevic regime (Mijatovic 2008) the latter (as turbo-folk) embraced its life-style and values (Kronja 2004). In England however the process seems to be different. Rock and roll and pop musicians, prior to the 1964 'first British invasion' to America (and the rest of the world), imitated sounds from their American counterparts from places such as Memphis and Chicago. Nowadays some commentators recognize that popular music in England has taken the place and properties from folk music, changing evaluative dynamics and cultural hierarchies (Cloonan 1997; Morra 2013).

\section{Conclusion}


The main motivation of this research is to adopt a comparative perspective in order to cross-nationally revisit the omnivore thesis. From a conceptual point of view, this article understands musical taste groups as forms of social distinction (Tampubolon 2008b; Lizardo and Skiles 2012) with meanings based on specific discursive practices (Frith 1996) and historical national repertoires (Lamont 1992). Empirically, we analysed data from Austria, England, Israel and Serbia to develop these ideas in detail. The analytical strategy implemented consisted of detecting grouped patterns of taste and quantifying the impact of sociodemographic variables on the construction of these groups.

This research has focused on answering four research questions. Regarding the first and second, our results show that in every country analysed it is possible to find individuals with different levels and composition of musical likes and dislikes. As claimed by Frith (1996) but with caution, in the four countries examined in this study it is possible to detect in higher social positions the cultural elites of Frith's Art discourse coexisting with Popular and Folk in interchangeable middle and lower positions, to which it is also possible to add a group of cultural eclectics. The inclusion of country-specific variables allows us to understand how the distribution of respondents' dislikes and likes reflects cultural differences and defines the strength of cultural boundaries. Broadly speaking, Austrian, English and Israeli urban contemporary taste groups are quite similar in their preference of hip-hop and electronic music. However, the Serbian group expresses dislike of hip-hop and a positive opinion of folk. English, Israeli and Serbian local groups voice a strong like of traditional folk music and dislike of popular; however, Austrian local folk appear to be remarkably tolerant or indifferent of classical music while Austrian local popular prefer folk-rooted schlager. Austrian and English highbrows prefer jazz and classical along with rock and some local styles. Meanwhile, Israeli and Serbian highbrows are subdivided into those oriented to tolerate contemporary or traditional style.

In answer to our third research question, is musical eclecticism a feature spread across different societies?, our results suggest that in all analysed countries it is possible to detect a group of individuals with broad musical taste, defined as the intersection of these three discourses. However, conclusions regarding their composition and social positions cannot be directly generalised across countries. Having demonstrated that eclecticism is present in our analysed countries, we can provide an answer to our remaining research question. Are Austrian, English, Israeli and Serbian eclectics holders of higher social positions?Cultural omnivourism, as originally defined by Peterson and colleagues, it is not necessarily a widespread phenomenon. Austrian and English eclectic groups express constant probability of displaying any level of distaste or taste, evidence of openness but also of less intense feelings towards the music they like. Israeli and Serbian patterns suggest openness to liking a broader combination and amount of genres. Although eclectics in Israel and Serbia appear to display preferences in a similar way to traditional definitions of omnivourism, they do not necessarily belong to any national elite; only English and Austrian eclectics share socially advantaged positions with highbrow taste groups. Do they differ in terms of sociodemographic characteristics?They differ not only in terms of social and personal characteristics, but also in the way their tastes and distastes structure these groups. Although some of the detected patterns of eclecticism may fit with definitions of omnivourism by volume or composition, eclectics do not cross every cultural boundary.

In Austria and England eclectics tend to be middle aged, with a higher educational attainment and occupational class, mainly residing in Vienna or London. In Israel, being from an older age group, mostly Sephardic and from an intermediate educational level and occupational class are the features that define Israeli eclectics. Finally, in Serbia individuals of a young age, highly educated but from a middle occupational class tend to display eclectic taste. Clearly, age is the most important variable that defines how musical tastes and distastes are distributed across society. Again, to fully understand the meaning of this distinction and how it differs across countries, national historical and cultural repertories are the key interpretative tool. It is clear that Austrian and English taste groups reflect tension between young people with a preference for popular emerging styles as opposed to the more traditional tastes of folk and classical of the more adult population (Savage 2006; Reitsamer 2012). However, Israeli and Serbian groups are structured differently. In the case of Israel, this tension is also expressed in terms of the western-influenced popular styles preferred by young age cohorts and traditional music influenced by strong ethnic and religious roots (Regev 2000; Katz-Gerro, Raz and Yaish 2009). In the case of Serbia, younger age groups more frequently prefer globally known popular music, but also some of the highly diverse popular folk expressions. Older age groups diverge regarding the selection of musical folk forms closed to western influences (Cvetičanin, 2008).

Without a doubt, differences across eclectics patterns between countries and their positions within social structures, could be explained by several other aspects that define and shape national repertoires and cultural identities. Being out of this article's scope, we argue that this is the path to follow for future comparative research in cultural stratification. This research has shown that the meaning of patterns of musical likes and dislikes and particularly the one of eclectics differs according to locale. This corresponds to an accurate picture of national cultural domains, being only possible to detect using a combination of common and country-specific cultural indicators that adequately reflect the diversity of social structures of each country analysed. The results of this research echo the call of several authors to question the use of the concept of omnivorism (Lahire 2008; Atkinson 2011; Lizardo and Skiles 2012) and to extend cross-national comparative research (Katz-Gerro 2011). 
Beside the concerns mentioned earlier, this kind of interpretative work reflects boundaries which still persist in contemporary societies (Tampubolon 2010), however, we believe that the use of alternative conceptualisations alongside more refined methodologies is needed to elucidate how culture is socially stratified in four advanced societies. The greatest achievement of Peterson's cultural omnivore was to open a door to the acceptance of the existence of different patterns of consumption, apparently inconsistent with high-low culture distinctions derived from Bourdieu's. However, the cultural omnivore thesis as a standalone theoretical framework is not able to provide a complete answer, especially in relation to processes of social distinction.

The national repertoires approach this research uses, regardless of performing comparative or single case study research, makes imperative the need for vigilance on the way cultural items are labelled and ranked. To verify whether preferences delimitated or cross boundaries, these had to be defined according to a hierarchy that ties together musical works and artists in terms of aesthetic expectations from the market and audience. Moreover, their composition differs across nations. In this regard, the concept of national repertoires extends the scope of the study of taste, recognizing that differences in how cultural items are socially distributed are explained by (among other factors) the existence of social, historical and political differences between countries.

The next logical step is to assess to what degree it is possible to extrapolate our results to other cultural domains and national social structures and expand cross-national research to other domains and dimensions of cultural practices. On this last point, it would be interesting to analyse historical data to model the trajectories that genres follow over time, relative to their positions in cultural hierarchies, and to gather data from more countries with varied national repertoires to understand their impact on symbolic boundaries, musical hierarchies, patterns of preferences and distinctions. These aspects are some of the missing links in the subject which would enable a fuller understanding of the social meaning which patterns of contemporary musical practices have.

\section{Notes}

For a more detailed explanation, see Tampubolon (2008b), Bennett et al. (2009) and Prior (2013).

Primary or below:ISCED 1-2; Secondary:ISCED 3; Tertiary:ISCED 4-6.

For a detailed explanation, refer to Galindo-Garre, Vermunt and Bergsma (2004), Vermunt and Magidson (2005), and Galindo-Garre and Vermunt (2006).

Criterion used to evaluate and compare goodness of fit penalising in terms of model complexity. Models with lower BIC are preferred (Vermunt and Magidson 2008).

However, $23.34 \%$ of local and $29.48 \%$ of local uninformed groups have tertiary education. This highlights internal divisions among people that prefer country and western and classical.

Previous research in Israel highlights the importance of ethnicity in shaping cultural engagement (KatzGerro, Raz and Yaish 2007, 2009).

\section{References}

ATKINSON, W (2011) The context and genesis of musical tastes: Omnivorousness debunked, Bourdieu buttressed. Poetics, Vol. 39, p. 169-186. [doi:10.1016/j.poetic.2011.03.002]

BENNETT, T, SAVAGE, M, SILVA, EB, WARDE, A, GAYO-CAL, M and WRIGHT, D (2009) Culture, class, distinction. London: Routledge.

BINDER, D (2012) Musikalische geschmacksvielfalt als kulturelles kapital?. Vienna: Institut für Musiksoziologie.

BIRKELUND, GE and LEMEL, Y (2013) Lifestyles and social stratification: An explorative study of France and Norway. Comparative Social Research, Vol. 30, p. 189-220. [doi:10.1108/S01956310(2013)0000030011]

BOURDIEU, P. (1984[1979]) Distinction: A social critique of the judgement of taste[Translated by Richard Nice]. London: Routledge.

BREEN, R (2005) Foundations of a neo-Weberian class analysis. In approaches to class analysis, edited by Erick Olin Wright. Cambridge: Cambridge University Press.

CHAN, TW (2010) Social status and cultural consumption. Cambridge: Cambridge University Press. 
CHAN, TW and GOLDTHORPE, JH (2007) Social stratification and cultural consumption: Music in England. European Sociological Review, Vol, 23, p. 1-19.

CLOONAN, M (1997) State of the nation: "Englishness," pop, and politics in the mid?1990s.Popular Music and Society, Vol, 21, p. 47-70. [doi:10.1080/03007769708591667]

CVETIČANIN, P (2008) Cultural needs, habits and taste of citizens of Serbia and Macedonia Belgrade: Committee for Civic Initiative.

CVETI\&CCARON;ANIN, P and POPESCU, M (2011) The art of making classes in Serbia: Another particular case of the possible. Poetics, Vol, 39, p. 444-468. [doi:10.1016/j.poetic.2011.09.006]

DALOZ, P (2010) The Sociology of Elite Distinction. Hampshire: Palgrave. [doi:10.1057/9780230246836]

DE MENEZES, LM and LASAOSA, A (2007) Comparing fits of latent trait and latent class models applied to sparse binary data: An illustration with human resource management data. Journal of Applied Statistics, Vol, 34, p. 303-319. [doi:10.1080/02664760601004908]

ERICKSON, BH (1996) Culture, class and connections. American Journal of Sociology, Vol, 102, p. 217-251. [doi:10.1086/230912]

FORMANN, AK (2003) Latent class model diagnosis - A review and some proposals.Computational Statistics and Data Analysis, Vol, 41, p. 549-559. [doi:10.1016/S0167-9473(02)00186-X]

FRITH, S (1996) Performing rites. Evaluating popular music. New York: Oxford University press.

GALINDO-GARRE, F and VERMUNT, JK (2006) Avoiding boundary estimates in latent class analysis by Bayesian posterior mode estimation. Behaviormetrika, Vol, 33, p. 43-59. [doi:10.2333/bhmk.33.43]

GALINDO-GARRE, F, VERMUNT, JK and BERGSMA, WP (2004) Bayesian posterior estimation of logit parameters with small samples. Sociological Methods and Research, Vol, 33, p. 88-117. [doi:10.1177/0049124104265997]

HANQUINET, L (2013) Visitors to modern and contemporary art museums: Towards a new sociology of 'cultural profiles'. The Sociological Review, Vol, 61, p. 790-813. [doi:10.1111/1467-954X.12072]

HUBBER, M (2010) Wozu musik? Musikalische verhaltensweisen, vorlieben und einstellungen der Österreicher/innen. Vienna: Institut für Musiksoziologie.

HUDSON, R (2003) Songs of seduction: popular music and Serbian nationalism. Patterns of Prejudice, Vol, 37, p. 157-176. [doi:10.1080/0031322032000084688]

KAPLAN, D (2012). Institutionalizaded erasures: How global structures acquire national meanings in Israeli popular music. Poetics, Vol, 40, p. 217-236. [doi:10.1016/j.poetic.2012.03.001]

KATZ-GERRO, T (2002) Highbrow cultural consumption and class distinction in Italy, Israel, West Germany, Sweden, and the United States. Social Forces, Vol, 81, p. 207-229. [doi:10.1353/sof.2002.0050]

KATZ-GERRO, T (2011) Cross-national cultural consumption research: Inspirations and disillousions."Kölner Zeitschrift für Soziologie und Sozialpsychologie, Vol, 51, p. 339-360.

KATZ-GERRO, T, RAZ, S and YAISH, M (2007) Class, status, and intergenerational transmission of musical tastes in Israel. Poetics, Vol, 35, p. 152-167. [doi:10.1016/j.poetic.2007.03.003]

KATZ-GERRO, T, RAZ, S and YAISH, M (2009) How do class, status, ethnicity, and religiosity shape cultural omnivorousness in Israel? Journal of Cultural Economy, Vol, 33, p. 1-17. [doi:10.1007/s10824-0089088-5]

KRONJA, I (2004) Turbo folk and dance music in 1990s Serbia: Media, ideology and the production of spectacle." The Anthropology of East Europe Review, Vol, 22, p. 103-114.

LAHIRE, B (2008) The individual and the mixing of genres: Cultural dissonance and self-distinction. Poetics, Vol, 36, p. 166-188. [doi:10.1016/j.poetic.2008.02.001]

LAMONT, M (1992) Money, morals, and manners: The culture of the French and the American upper-middle class. Chicago: University of Chicago Press. [doi:10.7208/chicago/9780226922591.001.0001]

LARKEY, E (1992) Austropop: popular music and national identity in Austria.Popular Music, Vol, 11, p. 151-185. [doi:10.1017/S0261143000004980]

LEGUINA, A (2015) Musical distinctions in England: Understanding cultural homology and omnivorism through a methods comparison. Bulletin of Sociological Methodology, Vol, 126, 28-45. 
LIZARDO, O and SKILES. S (2009) Highbrow omnivorousness on the small screen? Cultural industry systems and patterns of cultural choice in Europe. Poetics, Vol, 37, p. 1-23. [doi:10.1016/j.poetic.2008.10.001]

LIZARDO, O and SKILES. S (2012) Reconceptualizing and Theorizing "Omnivorousness": Genetic and Relational. Sociological Theory, Vol, 30, p. 263-282. [doi:10.1177/0735275112466999]

MORRA, I (2013) Britishness, popular music, and national identity: the making of modern Britain New York and London: Routledge.

MIJATOVIC, B (2008) Throwing stones at the system: Rock music in Serbia during the 1990sMusic and Politics, Vol, 2, p. 1-20. [doi:10.3998/mp.9460447.0002.203]

OLLIVIER, M (2008) Modes of openness to cultural diversity: Humanist, Populist, practical, and indifferent omnivores. Poetics, Vol, 36, p. 120-147. [doi:10.1016/j.poetic.2008.02.005]

OLLIVIER, M, GAUTHIER, G and TRUONG AH (2009) Cultural classifications and social divisions: A symmetrical approach. Poetics, Vol, 37, p. 456-473. [doi:10.1016/j.poetic.2009.09.005]

PETERSON, RA (2005) Problems in comparative research: The example of omnivorousness. Poetics, Vol, 33, p. 257-282. [doi:10.1016/j.poetic.2005.10.002]

PETERSON, RA and SIMKUS, A (1992) How musical tastes mark occupational status group. In Cultivating Differences, edited by Michele Lamont and Marcel Fournier. Chicago: University of Chicago Press.

PRIOR, N (2013) Bourdieu and the sociology of music consumption: A critical assessment of recent developments. Sociology Compass, Vol, 7, p. 181-193. [doi:10.1111/soc4.12020]

REGEV, M (2000) To have a culture of our own: on Israeliness and its variantsEthnic and Racial Studies, Vol, 23, p. 223-247. [doi:10.1080/014198700329033]

REGEV, M (2011) Pop-rock music as expressive isomorphism: Blurring the national, the exotic, and the cosmopolitan in popular music. American behavioural scientist, Vol, 55, p. 228-573. [doi:10.1177/0002764211398079]

REITSAMER, R (2012) Born in the republic of Austria. The invention of rock heritage in Austria.International Journal of Heritage Studies, forthcoming.

RIMMER, M (2012) Beyond omnivores and univores: The promise of a concept of musical habitus."Cultural Sociology, Vol, 6, p. 299-318. [doi:10.1177/17499975511401278]

RUBIN, D.B (1987) Multiple Imputation for Nonresponse in Surveys New York : J. Wiley \& Sons. [doi:10.1002/9780470316696]

SAVAGE, M (2006) The musical field. Cultural Trends, Vol, 15, p. 159-174. [doi:10.1080/09548960600712975]

SAVAGE. M and GAYO-CAL, M (2011) Unravelling the omnivore: A field analysis of contemporary musical taste in the United Kingdom. Poetics, Vol, 39, p. 337-357. [doi:10.1016/j.poetic.2011.07.001]

SKRONDAL, A and RABE-HESKETH, S (2004) Generalized latent variable modeling: multilevel, longitudinal, and structural equation models. New York: Chapman \& Hall.

TAMPUBOLON, G (2008a). Revisiting omnivores in America circa 1990s: The exclusiveness of omnivores? Poetics, Vol, 36, p. 243-264. [doi:10.1016/j.poetic.2008.02.007]

TAMPUBOLON, G (2008b) Distinction in Britain, 2001-2004?European Societies, Vol, 10, p. 403-428. [doi:10.1080/14616690701326832]

THOMSON, K (2004) Cultural capital and social exclusion survey. Southampton: National centre for social research.

UNESCO (2012) International standard classification of education ISCED 2011. Montreal: UNESCO Institute for Statistics.

VAN EIJCK, K (2001) Social differentiation in musical taste patterns. Social Forces, Vol, 79, p. 1163-1184. [doi:10.1353/sof.2001.0017]

VERMUNT, JK and MAGIDSON, J (2005) Technical guide for Latent GOLD 4.0: Basic and advanced Belmont: Statistical Innovations Inc.

VERMUNT, JK and MAGIDSON, J (2008) LG-Syntax users guide: Manual for Latent GOLD 4.5 Syntax Module Belmont: Statistical Innovations Inc. 
VERMUNT, JK, VAN GINKEL, JR, VAN DER ARK, LA and SIJTSMA, K (2008) Multiple imputation of categorical data using latent class analysis. Sociological Methodology, Vol, 33, p. 369-297. [doi:10.1111/j.14679531.2008.00202.x]

WARDE, A and GAYO-CAL, M (2009) The anatomy of cultural omnivorousness: The case of the United Kingdom. Poetics, Vol, 37, p. 119-145. [doi:10.1016/j.poetic.2008.12.001]

YAISH, M and KATZ-GERRO, T (2012) Disentangling 'cultural capital': The consequences of cultural and economic resources for taste and participation. European Sociological Review, Vol, 28, p. 169-185. 